\title{
Auto-Injector Dosing Unit
}

National Cancer Institute

\section{Source}

National Cancer Institute. Auto-Injector Dosing Unit. NCI Thesaurus. Code C122630.

A dosing unit equal to the amount of active ing redient(s) contained in an auto-injector. 